\title{
IRON AS AN AGENT OF OXIDATIVE INJURY IN EXPERIMENTAL ATHEROSCLEROSIS
}

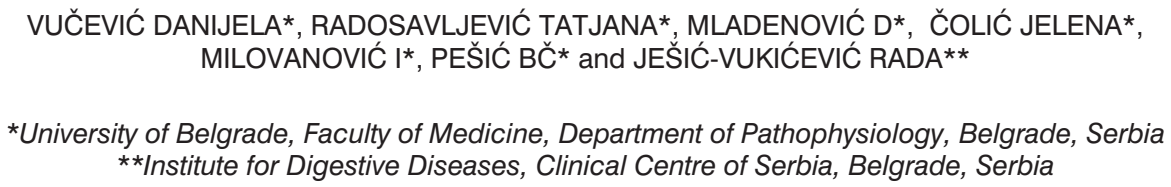

(Received 3rd June 2011)

Having in mind the importance of iron as a catalyst in some oxidative reactions, we examined the iron content in the serum and thoracic aorta tissue of rabbits with experimental atherosclerosis induced by hypercholesterolemic diet (4\% solution of crystalline cholesterol in edible oil). For this study three groups of rabbits were used: C - control group fed a standard diet for this species $(n=10), 0$ control group fed on an oil-containing diet $(n=10)$ and $\mathrm{Ch}$ experimental group fed on a hypercholesterolemic diet $(n=10)$. Experimental atherosclerosis was pathohistologically confirmed. Iron content was quantified by atomic absorptive spectrophotometry. After two-months of treatment a highly significant increase of iron content was registred in the serum and thoracic aorta tissue in Group Ch $(p<0.01)$ compared to the control group. In comparison with Group $C$ iron content in the thoracic aorta tissue was significantly $(p<0.01)$ decreased in Group O. A significant increase of iron content was registered in the thoracic aorta tissue iin Group Ch $(p<0.01)$ compared to Group $O$.

Our findings indicate a possible role of iron in the pathogenesis of experimental atherosclerosis.

Key words: iron, experimental atherosclerosis, hypercholesterolemic diet, rabbits

\section{INTRODUCTION}

Atherosclerosis is a progressive, multifactorial, diffuse, multisystemic, chronic, inflammatory disease, which is manifested by disorders of the vascular, immune and metabolic system (Ross, 1993; Ross, 1999; Libby, 2002). Pathogenesis of this disease is not fully understood. Numerous scientific theories, as well as functional, experimental and clinical studies have tried to explain the pathogenesis of atherosclerosis, whose frequent consequences, such are coronary disease and cerebral infarction are currently the leading worldwide cause of death. However, inspite the constantly growing body of biomedical knowledge and techniques, scientists are still far from a complete understanding 
of the molecular and cell system dysfunctions and their relevance in atherosclerosis. Additionally, one of the most widely accepted hypotheses offered to explain the development of atherosclerosis embraces oxidant/antioxidant imbalance as a central feature. Accordingly, atherosclerosis develops when balance between oxidants and antioxidants tips towards the destruction of vascular tissue by an increased oxidant burden and/or decreased antioxidant defense (Witztum, 1994; Libby, 1999; Ross, 1999; Libby, 2002).

Under oxidative stress low density lipoproteins (LDL) become trapped in the subendothelial space, where they can undergo progressive oxidation and be internalized by macrophages via scavenger receptors on the surface of these cells. Òhe internalization leads to the production of lipid peroxides and facilitates the accumulation of cholesteryl esters, resulting in the formation of foam cells. Oxidized LDL (ox-LDL) particles also cause endothelial dysfunction and injury, as well as foam cell necrosis, resulting in the release of lysosomal enzymes and necrotic debris (Ross, 1993; Wiitztum, 1994; Libby, 1999; Ross, 1999; Libby, 2002).

In atherosclerosis the endothelium emits signals that provide vascular smooth muscle proliferation and migration, platelet aggregation and thrombus formation. Namely, the endothelial expression of adhesion molecules promote atheroma infiltration of leukocytes and other blood-derived cells, so leading to vasoconstriction, thrombogenesis and fibrinolysis (Ross, 1993; Wiitztum, 1994; Ross, 1999; Libby, 2002; Brevetti et al., 2008).

Iron appears to be a relevant factor in free radical production, having in mind the importance of this transition metal as a potent catalyst in some oxidative reactions.

Chelates and complex compounds, that contain iron combined with adenosine triphosphate (ATP), guanosine triphosphate (GTP) and organic acids, as well as compounds consisting of iron combined with deoxyribonucleic acid (DNA) and lipids, have been implicated in cellular oxidant generation. Unsaturated fatty acids of polymorphonuclear leukocytes (PMN), monocytes and macrophages are particularly susceptible to the attack by oxidants (Gille and Sigler, 1995; De Greef et al., 1998; Witko-Sarsat et al., 2000; Dröge, 2002). Moreover, it has been shown that LDL susceptibility to oxidative modification was associated with serum iron concentration (Mukhopadhyay and Chatterjee, 1994; Acworth and Bailey, 1995; Lehotsky et al., 2002):

$$
\begin{aligned}
& \mathrm{O}_{2}+\text { cellular compounds } \rightarrow \mathrm{O}_{2}^{--}+\mathrm{H}_{2} \mathrm{O}_{2} \\
& \mathrm{O}_{2}^{-\cdot}+\mathrm{Fe}^{3+} \rightarrow \mathrm{O}_{2}+\mathrm{H}_{2} \mathrm{O}_{2} \\
& 2 \mathrm{O}_{2}^{-\cdot}+2 \mathrm{H}^{+} \rightarrow \mathrm{O}_{2}+\mathrm{H}_{2} \mathrm{O}_{2} \\
& \mathrm{Fe}^{2+}+\mathrm{H}_{2} \mathrm{O}_{2} \rightarrow \mathrm{Fe}^{3+}+\mathrm{OH}^{-} \\
& +\mathrm{OH} \cdot \rightarrow \text { lipid peroxidation }
\end{aligned}
$$

Lipid hydroperoxides in the presence of iron are capable of producing alcoxyl (lipid-O) and peroxyl radicals:

$$
\begin{aligned}
& \text { lipid- } \mathrm{O}_{2} \mathrm{H}+\mathrm{Fe}^{2+} \text { - complex } \rightarrow \mathrm{Fe}^{3+} \text { - complex }+\mathrm{OH}^{-}+\text {lipid-O } \\
& \text { lipid- } \mathrm{O}_{2} \mathrm{H}+\mathrm{Fe}^{3+} \text { - complex } \rightarrow \mathrm{Fe}^{2+} \text { - complex }+\mathrm{H}^{+}+\text {lipid- } \mathrm{O}_{2} .
\end{aligned}
$$


Acta Veterinaria (Beograd), Vol. 61, No. 5-6, 631-641, 2011.

Reactive oxygen species (ROS), such as the superoxide anion radical $\left(\mathrm{O}_{2}^{--}\right)$ and hydrogen peroxide $\left(\mathrm{H}_{2} \mathrm{O}_{2}\right)$, are involved in iron oxidation and reduction processes, which lead to generation of ferryl $/\left[\mathrm{Fe}-\mathrm{OH}^{3+}\right]$ and $[\mathrm{Fe}-\mathrm{O}]^{2+} /$, and preferryl $/[\mathrm{Fe}-\mathrm{O}]^{3+}$ and $\left[\mathrm{Fe}^{3+}-\mathrm{O}_{2} \cdot\right] /$ radicals. These very potent radicals stimulate the further propagation of lipid peroxidation. Extensive lipid peroxidation can impair membrane function, inactivate membrane bound receptors and enzymes, disturb membrane fluidity and increase permeability (Halliwell and Chirico, 1993; Halliwell, 1996; Janzen, 1996; Halestrap, 2002; Halestrap et al., 2002).

Since iron-mediated oxidative injury may be relevant to the pathogenesis of atherosclerosis, we directed our experimental goal into measuring the iron content in the serum thoracic aorta tissue of Chinchilla rabbits affected with experimental atherosclerosis induced by hypercholesterolemic diet.

\section{MATERIAL AND METHODS}

Experiments were performed on Chinchilla rabbits of both sexes, weighting about 1600-2000 g, raised at Military Medical Academy, Belgrade. Animals were kept under standard laboratory conditions (temperature $22 \pm 1^{\circ} \mathrm{C}$, relative humidity 50\%, 12/12 h light dark cycle with lights switched on at 9 AM) with free access to food and tap water. The study was performed according to the Guidelines for Animal Study No 282-12/2002 and was approved by The Ethic Committee of the Faculty of Medicine, University of Belgrade. The investigated animals $(n=30)$ were divided into three groups (ten animals each):

1. (C)-control group fed on a standard diet for this species,

2. (O)-control group fed on an oil-containing diet. These animals received 6 $\mathrm{mL}$ of edible oil through a gastric tube five times a week for two months and

3. (Ch)-experimental group fed on a hypercholesterolemic diet. These animals received a $4 \%$ solution of crystalline cholesterol (ICN Galenika) in $6 \mathrm{~mL}$ of edible oil through a gastric tube five times a week for two months.

After two months of treatment the respective groups of rabbits were bled and serum was separated from the blood samples and stored at $-20^{\circ} \mathrm{C}$. Rabbits were sacrificed by air embolism (air injected intracardially). Thoracic aorta tissue sections, obtained from each group of rabbits, were placed in a formalin solution to be subsequently molded and stained with hematoxylin eosin.

Thoracic aorta tissue specimens were analyzed histologically by light microscopy (magnification $100 \mathrm{X}$ ).

The iron content in the serum was determined by atomic absorption spectrophotometry (VARIAN AA-5).

The values of parameters for individual animals were averaged and standard deviation (SD) was calculated. Statistical evaluation of results was performed using ANOVA and Fisher-post hoc test. A p value of less than 0.05 was considered significant. Statistical analysis of data was carried out using a computer with the assistance of a statistical software package - STATISTICA 6.0 and SPSS 8.0 Professional Edition. 


\section{RESULTS}

The mean iron content in rabbit's serum and thoracic aorta tissue is presented in Table 1. As can be seen, in comparison with Group Ch serum iron content was significantly decreased in the Group C $(p<0.01)$.

Table1. Iron content in serum and thoracic aorta tissue of investigated animals

\begin{tabular}{|l|c|c|}
\hline Group & $\begin{array}{c}\text { Serum iron content } \\
\mu \mathrm{g} / \mathrm{mL}\end{array}$ & $\begin{array}{c}\text { Iron content in thoracic aorta tissue } \\
\mu \mathrm{g} / \mathrm{g}\end{array}$ \\
\hline Control $(\mathrm{n}=10)$ & $5.05 \pm 0.97$ & $19.90 \pm 3.97$ \\
\hline Oil $(\mathrm{n}=10)$ & $5.31 \pm 0.93$ & $14.79 \pm 3.09^{\star *}$ \\
\hline Cholesterol $(\mathrm{n}=10)$ & $5.37 \pm 1.49^{\star \star}$ & $29.74 \pm 6.85^{\star *} \# \#$ \\
\hline
\end{tabular}

Values are expressed as means \pm SD. For testing the difference among groups one-way ANOVA with Fisher's post hoc test was used.

${ }^{* *} p<0.01$ vs. control group; \#\#p<0.01 vs. oil group

Nonsignificant increase in iron content was registered in serum of Group $\mathrm{O}$ compared to Group C ( $p>0.05)$.

In comparison with Group O serum iron content was nonsignificantly increased in the Group Ch ( $p>0.05)$.

Highly significant increase of iron content was registered in thoracic aorta tissue of Group Ch compared to both control groups $(p<0.01)$.

In comparison with Group C iron content in thoracic aorta tissue was significantly decreased in Group $\mathrm{O}(\mathrm{p}<0.01)$.

Figure 1-3 shows the thoracic aorta tissue of rabbits.

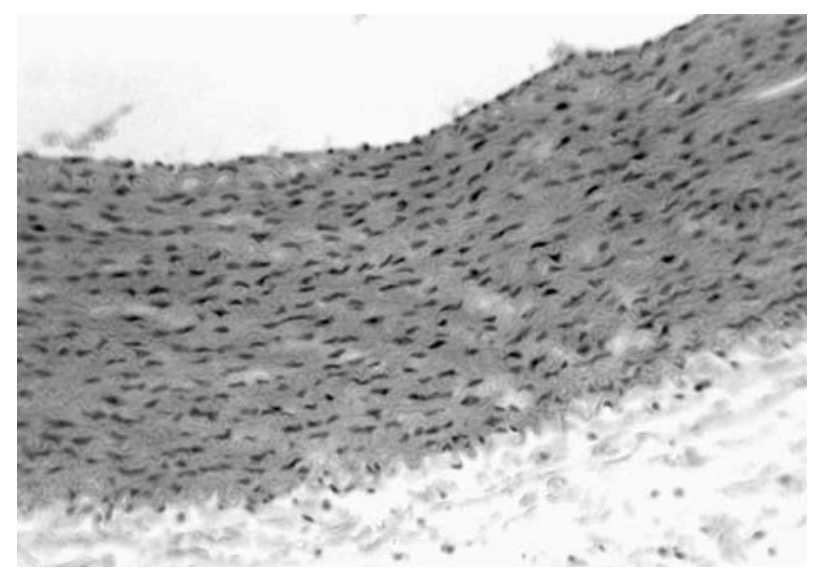

Figure 1. Thoracic aorta tissue of a control rabbit (C)

The thoracic aorta tissue of the control group is without atherosclerotic changes. 
Acta Veterinaria (Beograd), Vol. 61, No. 5-6, 631-641, 2011.

Thoracic aorta tissue of a control rabbit $(C)$ is presented in Figure 1. The thoracic aorta tissue of the control group is without atherosclerotic changes.

Thoracic aorta tissue of a rabbit on oil-containing diet $(O)$ is presented in Figure 2. An initial phase of atherosclerosis can be observed. Namely, the oilcontaining diet in somehow leads to disturbance of iron metabolism and may augment the effects of this transition metal. It is well-known that iron in early atherosclerotic lesions is primarily localized in the lysosomes of foam cells (Meyers, 2000). Thus, considering the role of iron in enzyme catalyzed reactions, the immunogenic activity of edible oil may be involved with the findings presented in this study (Vucevic et al., 2005) (Figure 2).

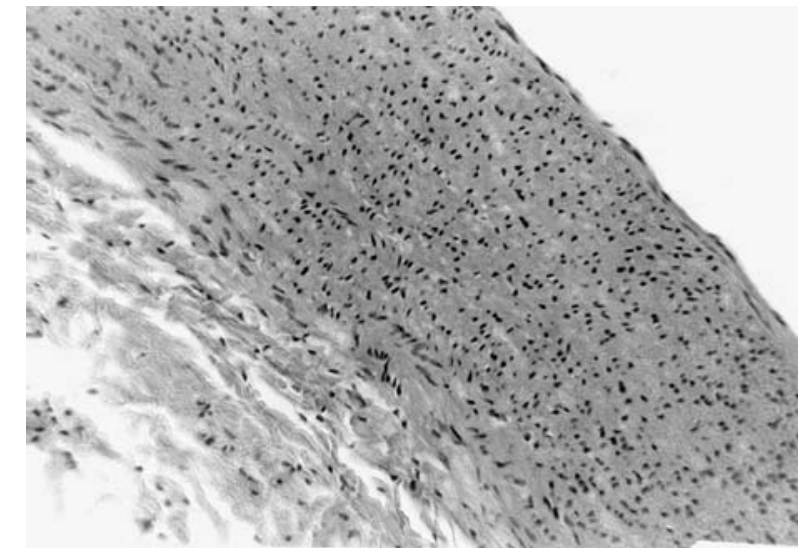

Figure 2. Thoracic aorta tissue of a rabbit fed on an oil-containing diet (O) An initial phase of atherosclerosis can be observed.

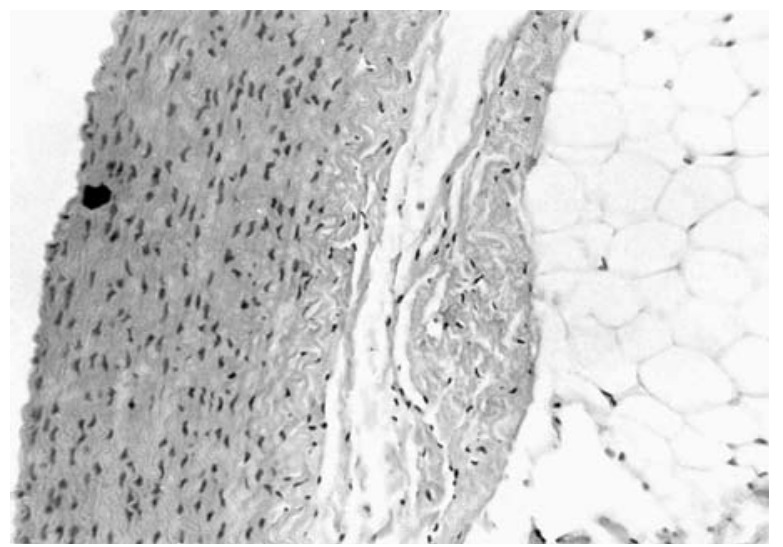

Figure 3. Thoracic aorta tissue of a rabbit fed on a hypercholesterolemic diet (Ch) with evident atherosclerosis

Striking thickening of the intima can be noticed. Derangement of internal elastic lamina, that is locally damaged, can be also noticed. Lipid laden cells appeared between the endothelium and subendothelial tissue. 
Thoracic aorta tissue of a rabbit fed on a hypercholesterolemic diet (Ch) with evident atherosclerosis is presented in Figure 3. Striking thickening of the intima can be noticed. Derangement of the internal elastic lamina, which is locally damaged, can be also observed. Lipid laden cells appear between the endothelium and subendothelial tissue. After two months of treatment the thoracic aorta tissue of hypercholesterolemic rabbits accumulated large amounts of lipids. Cholesterol and cholesteryl ester atheromatously degenerated the wall of the thoracic aorta. This alteration is not observed in any other investigated group of rabbits. The amount of iron deposition in the aorta has been directly associated with the severity of the atherosclerosis (Meyers, 2000). Similar to results of our previos study (Vucevic et al., 2005), the cholesterol immunostimulation capacity is related to iron content and the pathophysiological findings are also observed in the thoracic aorta tissue of Group Ch (Figure 3).

\section{DISCUSSION}

In the present study, iron content in the serum was not significantly increased in Group $\mathrm{O}$ in comparison with Group C. On the contrary, highly significant increase of iron content was registered in the serum of Group Ch $(p<0.01)$ compared to the control group. These results may be associated with oxidative stress, since the production of ROS depends on iron as a catalyst. The increase of iron content in serum of $\mathrm{Ch}$ and Group $\mathrm{O}$ may be of importance in the development of pathomorphological changes in the thoracic aorta tissue of these animals (Figures 2 and 3 ). Besides, iron has been demonstrated to initiate and potentiate the inflammatory response (Henle et al., 1999; Heunks and Dekkhuijzen, 2000; Welch et al., 2002; Urso and Clarkson, 2003; Krettek et al., 2003). Inflammation is characterized by early neutrophilic infiltration followed by an increased number of macrophages, epithelial, mast and other metabolically active aorta tissue cells. Increased numbers of immune and inflammatory effector cells in areas adjacent to endothelial injury could alter the oxidant/antioxidant balance in the arterial wall. Namely, the activated inflammatory cells spontaneously secrete exaggerated amounts of highly toxic ROS $\left(\mathrm{O}_{2} \cdot-\right.$ and $\left.\mathrm{H}_{2} \mathrm{O}_{2}\right)$. As a consequence, both the absolute increase in cell numbers as well as the enhanced oxidant release drastically amplify the oxidant burden in fragile aorta tissue (Droge, 2002; Fenster et al., 2003). There is substantial evidence suggesting that phagocyte-derived oxidants may inactivate $\alpha_{1}$-protease inhibitors and thereby allow proteases to produce more extensive connective tissue destruction. It seems that in this model the increased number and dysfunction of immune and inflammatory effector cells, as well as cholesterol immunostimulating capacity, are also related to iron content in the serum and the pathohistological findings observed in the thoracic aorta tissue in Ch and Group O (Figure 2 and 3) (Wiitztum, 1994; Gille and Sigler, 1995; Halliwell, 1996; Ross, 1999; Droge, 2002). Additionally, the oil-containing diet in some way disturbs iron metabolism. Thus, findings presented in this study may be involved in the immunogenic activity of edible oil (Figure 2) (Djordjevic, 1978; Zunic, 1997; Vucevic, 1999, Vucevic et al., 2005). 
Acta Veterinaria (Beograd), Vol. 61, No. 5-6, 631-641, 2011.

Highly significant increase of iron content was registered in the thoracic aorta tissue of Group Ch compared to both control groups $(p<0.01)$. These results of our study could be related to the significant increase of metallocollagenolytic activity in the aorta tissue, that refers to an extensive collagenolysis in the aorta. These results may also be explained as a specific response of aorta tissue under the circumstances of massive hypercholesterolemia (Ross, 1993; Gille and Sigler, 1995; Halliwell, 1996). Namely, because of the extreme sensitivity of rabbits to dietary cholesterol, this experimental protocol causes massive increases of serum cholesterol content in $\mathrm{Ch}$ and Group O. Since cholesterol is an extremely immunogenic molecule, massive hypercholesterolemia induced in rabbits by special diets may increase the local lymphoproliferative response and also may alter the oxidant-antioxidant balance in the aorta tissue (Berliner, 2002; Wick et al., 2004). Pathohistological analysis of the thoracic aorta tissue specimens obtained from rabbits fed on a hypercholesterolemic diet indicates changes that refer to evident atherosclerosis (Figure 3).

Mechanisms involved in iron-catalyzed oxidative endothelial injury are still not fully understood. Direct endothelial toxicity, inactivation of enzymes required to maintain the integrity of the aorta tissue, alteration of the protease-antiprotease balance to favor protease activity, and augmentation of ROS formation have been postulated to account for the development of atherosclerosis.

It was reported that the release of iron from ferritin by the action of $\mathrm{O}_{2} \cdot$, generated by membrane-bound nicotinamide-adenine dinucleotide phosphate (NADPH) oxidase from NADPH could contribute to oxidative damage by making iron available for the site-specific Haber-Weiss reaction (Welch et al., 2002; Williams et al., 2002). An association of $\mathrm{O}_{2}{ }^{--}$with connective tissue injury is suggested by the fact that $\mathrm{O}_{2} \cdot$ generated by xanthine oxidase inhibits collagen gelation (Greenwald and Moy, 1979) and depolymerizes purified hyaluronic acid (McCord, 1974). It is possible, therefore, that $\mathrm{O}_{2}{ }^{-}$released by stimulated endothelial cells may injure the matrix of the microvascular, as well as the perivascular tissue (Libby, 2002; Wick et al., 2004). Furthermore, iron-mediated oxidation was involved in LDL modifications, that lead to the uptake of these molecules by "scavenger receptors" present on macrophages with the resultant development of foam cells (Buhl et al., 1994).

In rabbits, after a one-month treatment on a hypercholesterolemic diet one can observe foam cell formation in the thoracic aorta tissue (Haslam, 1994). Additionally, alterations in the cholesterol/phospholipid ratio could disturb membrane fluidity, so endothelial damage may be facilitated by promotion of vascular immune reactions (Wilsher et al., 1988). It has been shown that an excessive release of lysosomal enzymes from macrophages with subsequent aorta tissue destruction may be induced by cholesterol.

LDL particles are the major cholesterol transporting vehicle in the organism. Hypercholesterolemia leads to chronic presence of LDL particles in the arterial wall. Insudation of LDL is promoted by elevated plasma LDL concentrations and endothelial damage. Lipids and proteins derived from circulating LDL accumulate both within cells and in the extracellular space. It is now widely held that injury 
from high cholesterol levels is actually a result of cytotoxic forms of LDL (Falk et al., 1995).

Atherosclerosis is a disease involving both oxidative modifications and disbalance of the immune system. Modifications of LDL particles that can favor foam cell formation include oxidation, aggregation, enzymatic modification, complexing with immunoglobulins, and possibly others (Ross, 1999). All lipid classes (sterols, phospholipid fatty acids, cholesteryl esters and triglycerides) and protein particles are susceptible to oxidative modification. Ox-LDL particles are chemotactic for monocytes. Ox-LDL particles have also been associated with an increase in monocyte binding to endothelial cells in humans. Moreover, they inhibit macrophage motility from the arterial wall into the circulation and induce cholesterol accumulation in smooth muscle vascular cells. Oxidative cholesterol products derived from LDL particles appear capable of activating hydroxymethylglutaryl-coenzyme A reductase (HMG-CoA reductase). They can suppress the synthesis of the LDL-receptor gene and contribute to the maintainance of the increased LDL value in the circulation (Steinberg and Lewis, 1997). Thus, the highly significant increase of iron content, that was registered in the thoracic aorta tissue of Group Ch $(p<0.01)$ compared to both control groups in this model of experimental atherosclerosis, corresponds to previously mentioned literature data.

On the other hand, in comparison with Group $C$ iron content in the thoracic aorta tissue was significantly $(p<0.01)$ decreased in Group O. Inflammatory effector cell infiltration and the oil-containing diet in some manner lead to the disturbance of homeostatic mechanisms in the thoracic aorta tissue and may be related to the finding presented in this study (Figure 2). Our result is strongly related with the data from other studies (Djordjevic, 1978; Zunic, 1997; Vucevic 1999; Vucevic et al., 2005; Vucevic et al., 2007), too. It is well known that iron which has been released into the cell must either be used immediately for biosynthesis or stored in a safe form. Storage, as well as transport systems, must function rapidly and be completely reversible under physiological conditions in order to preclude local excess (Kaim and Schwederski, 1996). Additionally, our finding could also be explained by an efficient antioxidant activity in the thoracic aorta tissue of animals fed on an oil-containing diet.

Efficacy of our experimental procedure was histologically confirmed. In rabbits fed on hypercholesterolemic diet one can observe the development of atherosclerosis (Figure 3).

An initial phase of atherosclerosis can be observed in the thoracic aorta tissue of rabbits fed the oil-containing diet $(O)$ (Figure 2).

Our findings indicate a possible role of iron in the pathogenesis of experimental atherosclerosis. The involvement of ROS and lipid peroxidation in disease such as atherosclerosis has focused much scientific interest on lipid peroxidation processes, outlining a possible role of iron as an agent of oxidative tissue damage. Furthermore, the questions that this manuscript raises about the potential mechanisms of iron oxidative activity will provide an exciting basis for future research into the mechanisms of iron mediated oxidative endothelial injury. 
Acta Veterinaria (Beograd), Vol. 61, No. 5-6, 631-641, 2011.

Vučević Danijela et al.: Iron as an agent of

oxidative injury in experimental atherosclerosis

ACKNOWLEDGEMENTS:

This work was supported by the Ministry for Science and Technological Development of Serbia, Grant \# 175015.

Address for correspondence:

Danijela Vučević MD, PhD

Department of Pathophysiology

Faculty of Medicine, University of Belgrade

Dr Subotica 9

11000 Belgrade, Serbia

E-mail: danibovuc@med.bg.ac.rs; denihol@yahoo.com

\section{REFERENCES}

1. Acworth IN, Bailey B, 1995, The handbook of oxidative metabolism, Boston: ESA Inc.

2. Berliner J, 2002, Lipid oxidation products and atherosclerosis, Vasc Pharmacol, 38, 187-91.

3. Brevetti G, Schiano V, Chiariello M, 2008, Endothelial dysfunction: A key to the pathophysiology and natural history of peripheral arterial disease, Atherosclerosis, 197, 1-11.

4. Buhl R, Stahl E, Meier-Sydow J, 1994, In vivo assesssment of pulmonary oxidant damage: the role of bronchoalveolar lavage, Monaldi Arch Chest Dis, 49, 3 Suppl1, 1-8.

5. De Greef KE, Ysebaert DK, Ghielli M, Vercauteren S, Nouwen EJ, Eyskens E, 1998, Neutrophils and acute ischemia-reperfusion injury, $J$ Nephrol, 11, 110-22.

6. Dröge W, 2002, Free radicals in the physiological control of cell function, Physiol Rev, 82, 47-95.

7. Djordjevic G, 1978, Contribution to the study of pulmonary emphysema development during experimental arteriosclerosis, PhD Thesis, School of Medicine, University of Belgrade.

8. Falk E, Shah PK, Fuster V, 1995, Coronary plaque disruption, Circulation, 92, 657-71.

9. Fenster BE, Tsao PS, Rockson SG, 2003, Endothelial dysfunction: clinical strategies for treating oxidant stress, Am Heart J, 146, 218-26.

10. Gille G, Sigler K, 1995, Oxidative stress and living cells, Folia Microbiol, 2, 131-52.

11. Greenwald R, Moy WW, 1979, Inhibition of collagen gelation by action of superoxide radical, Arthritis Rheum, 22, 251.

12. Halestrap $A P, 2002$, The mitochondrial permeability transition - a pore way for the heart to die, $J$ Clin Bas Cardiol, 5, 29-41.

13. Halestrap AP, McStay GP, Clarke SJ, 2002, The permeability transition pore complex: another view, Biochimie, 84, 153-66.

14. Halliwell B, 1996, Antioxidants in human health and disease, Ann Rev Nutr, 16, 33-50.

15. Halliwell B, Chirico S, 1993, Lipid peroxidation: its mechanism, measurement and significance, Am $J$ Clin Nutr, 57, 715-25.

16. Haslam PL, 1994, Foamy macrophages in granulomatous lung diseases, Sarcoidosis, 11, 114-8.

17. Henle ES, Han Z, Tang N, Rai P, Luo Y, Linn S, 1999, Sequence-specific DNA cleavage by Fe ${ }^{2+-}$ mediated Fenton reactions has possible biological implications, J Biol Chem, 274, 962-71.

18. Heunks LMA, Dekkhuijzen PNR, 2000, Respiratory muscle function and free radicals: from cell to COPD, Thorax, 55, 704-16.

19. Janzen EG, 1996, The fate of the free radical, Redox Report, 2, 3, 155-9.

20. Kaim W, Schwederski B, 1996, Bioinorganic Chemistry: Inorganic Elements in the Chemistry of Life. An Introduction and Guide, John Wiley \& Sons, New York.

21. Krettek A, Sukhova GK, Libby $P, 2003$, Elastogenesis in human arterial disease. A role for macrophages in disordered elastin synthesis, Arterioscler Thromb Vasc Biol, 23, 582-7.

22. Lehotsky J, Kaplan P, Matejovicova M, Murin R, Racay P, Raeymaekers L, 2002, lon transport systems as targets of free radicals during ischemia reperfusion injury, Gen Physiol Biophys, 21, 1, 31-7.

23. Libby $P$, 1999, Changing concepts of atherogenesis, J Inter Med, 247, 349-58.

24. Libby $P$, 2002, Inflammation in atherosclerosis, Nature, 420, 19/26, 868-74. 
25. McCord JM, 1974, Free radicals and inflammation: protection of synovial fluid by superoxide dismutase, Science, 185, 529.

26. Meyers DG, 2000, The iron hypothesis: does iron play a role in atherosclerosis, Transfusion, 40 , 1023-29.

27. Mukhopadhyay CK, Chatterjee IB, 1994, Free metal ion-independent oxidative damage of collagen. Protection by ascorbic acid, J Biol Chem, 269, 48, 30200-5.

28. Ross $R, 1993$, The pathogenesis of atherosclerosis: a perspective for the 1990s, Nature, 362, 8019.

29. Ross R, 1999, Atherosclerosis - an inflammatory disease, $N$ Engl J Med, 340, 2, 115-26.

30. Steinberg D, Lewis A, 1997, Oxidative modification of LDL and atherogenesis, Circulation, 95, 4, 1062-71.

31. Urso ML, Clarkson PM, 2003, Oxidative stress, exercise and antioxidant supplementation, Toxicology, 189, 41-54.

32. Vucevic $D, 1999$, Importance of iron in pathogenesis of pulmonary emphysema in rabbits induced by hypercholesterolemic diet and possible protective role of vitamine E, Masters thesis, School of Medicine, University of Belgrade.

33. Vucevic D, Pesic B, Djarmati D, Djordjevic-Denic G, Radosavljevic T, Todorovic V et al., 2005, The effect of tocopherol on serum iron content in experimental atherosclerosis, Acta Veterinaria, 55, 2-3, 131-45.

34. Vucevic D, Milovanovic I, Mladenovic D, Zunic-Bozinovski S, Radosavljevic T, Stojanovic J, et al., 2007, The effect of tocopherol on serum lipid profile in pulmonary emphysema induced by hypercholesterolemic diet, Acta Veterinaria, 57, 4, 303-20.

35. Welch KD, Davis TZ, Aust SD, 2002, Iron autoxidation and free radical generation: effects of buffers, ligands and chelators, Arch Biochem Biophys, 397, 2, 360-9.

36. Wick G, Knoflach $M, X u Q, 2004$, Autoimmune and inflammatory mechanisms in atherosclerosis, Annu Rev Immunol, 22, 1111-43.

37. Williams MJA, Poulton R, Williams S, 2002, Relationship of serum ferritin with cardiovascular risk factors and inflammation in young men and women, Atherosclerosis, 165, 179-84.

38. Wilsher ML, Hughes DA, Haslam PL, 1988, Immunoregulatory properties of pulmonary surfactant: influence of variations in the phospholipid profile, Clin Exp Immunol, 73, 117-22.

39. Witko-Sarsat V, Rieu P, Descamps-Latscha B, Lesavre P, Halbwachs-Mecarelli L, 2000, Neutrophils: molecules, functions and pathophysiological aspects, Lab Invest, 80, 5, 617-53.

40. Witztum JL, 1994, The oxidation hypothesis of atherosclerosis, Lancet, 344, 793-5.

41. Zunic S, 1997, Bronchoalveolar lavage and oligoelements in pulmonary emphysema in rabbits induced by cholesterolemic diet, PhD Thesis, School of Medicine, University of Belgrade.

\title{
GVOŽĐE KAO AGENS OKSIDACIJSKOG OŠTEĆENJA U EKSPERIMENTALNOJ ATEROSKLEROZI
}

\author{
VUČEVIĆ DANIJELA, RADOSAVLJEVIĆ TATJANA, MLADENOVIĆ D, ČOLIĆ JELENA, \\ MILOVANOVIĆ I, PEŠIĆ BČ i JEŠIĆ-VUKIĆEVIĆ RADA
}

\section{SADRŽAJ}

S obzirom na ulogu gvožđa kao katalizatora u reakcijama nastanka slobodnih radikala važnih u patogenezi ateroskleroze, cilj našeg rada je bio da se ispita sadržaj ovog oligoelementa u serumu i tkivu torakalne aorte kunića sa eksperimentalnom aterosklerozom izazvanom hiperholesterolskom dijetom (4\% kristalni 
Acta Veterinaria (Beograd), Vol. 61, No. 5-6, 631-641, 2011.

Vučević Danijela et al.: Iron as an agent of

oxidative injury in experimental atherosclerosis

rastvor holesterola u jestivom ulju). Ispitivane životinje su podeljene u tri grupe: K-kontrolna grupa na dvomesečnoj ishrani uobičajenoj za ovu životinjsku vrstu

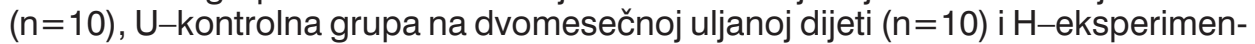
talna grupa na dvomesečnoj hiperholesterolskoj dijeti $(n=10)$. Eksperimentalna ateroskleroza je patohistološki potvrđena. Sadržaj gvožđa je određivan metodom atomske apsorpcione spektrofotometrije. Povećanje sadržaja gvožđa u serumu životinja $\mathrm{H}$ grupe u odnosu na kontrolne vrednosti je bilo visoko statistički značajno $(p<0,01)$. $U$ tkivu torakalne aorte životinja $H$ grupe $u$ odnosu na torakalno tkivo aorte životinja $\mathrm{K}$ grupe, nađeno je statistički visoko značajno povećanje koncentracije gvožđa $(p<0,01)$. U poređenju sa K grupom, statistički visoko značajno smanjenje $(p<0,01)$ sadržaja gvožđa zabeleženo je u torakalnom tkivu aorte životinja U grupe. Naši rezultati ukazuju na moguću ulogu gvožđa u nastanku eksperimentalne ateroskleroze. 